\title{
PENGEMBANGAN PERANGKAT PEMBELAJARAN DENGAN MODEL PEMBELAJARAN KOOPERATIF TIPE INVESTIGASI KELOMPOK PADA MATERI KESEBANGUNAN DAN SIMETRI DI KELAS V SEKOLAH DASAR
}

\author{
Sudarmini ${ }^{1}$, Siti Maghfirotun Amin ${ }^{2}$, Roesminingsih ${ }^{3}$ \\ Pendidikan Dasar, Pascasarjana Universitas Negeri Surabaya \\ email: sudarmini79@yahoo.co.id
}

\begin{abstract}
Abstrak
Penelitian ini merupakan penelitian pengembangan yang bertujuan untuk mengembangkan dan memperoleh perangkat pembelajaran matematika menggunakan model pembelajaran kooperatif tipe investigasi kelompok yang valid, praktis dan efektif, serta mendeskripsikan keefektifan pembelajaran setelah diterapkannya model pembelajaran kooperatif tipe investigasi kelompok pada materi kesebangunan dan simetri di kelas V Sekolah Dasar. Perangkat pembelajaran yang dikembangkan adalah rencana pelaksanaan pembelajaran (RPP), lembar kerja siswa (LKS), dan instrumen penilaian yaitu tes hasil belajar, lembar penilaian afektif, dan lembar penilaian psikomotor. Pengembangan perangkat pembelajaran mengikuti prosedur pengembangan Plomp yang meliputi lima tahap, yaitu: (1) investigasi awal, (2) desain, (3) realisasi/konstruksi, (4) tes, evaluasi, dan revisi, dan (5) implementasi. Tempat penelitian di SD Al Fatah Wiyung Surabaya, dengan objek penelitian adalah siswa kelas VB yang berjumlah 19 siswa sebagai kelas ujicoba lapangan, dan siswa kelas VA yang berjumlah 25 siswa sebagai kelas implementasi. Desain ujicoba menggunakan one group pretest posttest design dengan teknik analisis deskriptif kuantitatif dan deskriptif kualitatif. Instrumen penelitian terdiri dari lembar validasi perangkat pembelajaran, lembar pengamatan kemampuan guru mengelola pembelajaran, lembar pengamatan aktivitas siswa dalam pembelajaran, dan lembar angket respon siswa. Adapun pengumpulan data dilakukan dengan teknik observasi , tes, metode dokumentasi, dan angket respon siswa.

Kualitas hasil pengembangan perangkat pembelajaran ditandai dengan: 1). Kevalidan perangkat pembelajaran adalah valid dengan rentang rata-rata total validitas $3,4 \leq R T V \leq 3,7$ koefisien validitas butir tes soal $\geq 0,4$ mencapai kriteria cukup, reliabilitas tes adalah $\alpha=0,73$ dan berderajat sedang. 2) Kepraktisan perangkat pembelajaran yang ditunjukkan melalui hasil kemampuan guru mengelola pembelajaran diperoleh skor rerata 3,6 berkriteria baik. 3) Keefektifan perangkat pembelajaran meliputi: a) Hasil belajar siswa pada ranah kognitif mencapai ketuntasan belajar siswa secara klasikal sebesar 78,9\% rata-rata kelas adalah 3,28/B+. b) Hasil belajar siswa pada ranah afektif mencapai ketuntasan belajar siswa secara klasikal sebesar 89,5\% dan berpredikat akhir baik. c) Hasil belajar siswa pada ranah psikomotor mencapai ketuntasan belajar siswa secara klasikal sebesar 94,7\% dan capaian optimum kelas adalah 3,61/A-. d) Waktu aktivitas siswa dalam pembelajaran sesuai dengan kriteria batas yang ditetapkan dengan toleransi 10\%. e) Angket respon siswa terhadap perangkat pembelajaran yang dikembangkan mencapai persentase $83,5 \%$.

Hasil uji keefektifan perangkat pembelajaran pada kelas implementasi ditunjukkan melalui: 1) Skor rerata kemampuan guru mengelola pembelajaran selama 3 kali pertemuan adalah 3,63 dan berpenilaian umum sangat baik. 2) Hasil belajar siswa pada ranah kognitif mencapai ketuntasan belajar siswa secara klasikal sebesar 76,0\% rata-rata kelas adalah 2,95/B. 3) Hasil belajar siswa pada ranah afektif mencapai ketuntasan belajar siswa secara klasikal sebesar $100 \%$ dan berpredikat akhir baik. 4) Hasil belajar siswa pada ranah psikomotor mencapai ketuntasan belajar siswa secara klasikal sebesar 96,0\% dan capaian optimum kelas adalah 3,45/B+. 5) Waktu aktivitas siswa dalam pembelajaran sesuai dengan kriteria batas yang ditetapkan dengan toleransi $10 \%$. 6) Angket respon siswa terhadap perangkat pembelajaran yang dikembangkan mencapai persentase $84,0 \%$.

Berdasarkan hasil uji coba lapangan dan implementasi maka dapat disimpulkan bahwa perangkat pembelajaran yang dihasilkan dengan model pembelajaran kooperatif tipe investigasi kelompok ini memenuhi kriteria kualitas perangkat yang layak digunakan yaitu kevalidan, kepraktisan, dan keefektifan. Selain itu dengan uji keefektifan pembelajaran, hasil perangkat pembelajaran yang dikembangkan ini dapat meningkatkan hasil belajar siswa menjadi lebih baik
\end{abstract}

Kata Kunci: perangkat pembelajaran, model pembelajaran kooperatif, investigasi kelompok, kesebangunan, simetri.

\begin{abstract}
This research is a development that aims to develop and acquire the learning of mathematics using cooperative learning model type group investigation valid, practical and effective, as well as describe the effectiveness of study after the implementation of cooperative learning model group investigation on the material similarity and symmetry in the fifth grade primary school. Learning instruments are being developed lesson plan (RPP), student work sheet (LKS), and assessment instruments that test learning outcomes, assessment sheets affective, and psychomotor assessment sheet. Development of the learning device following the procedure Plomp
\end{abstract}


development that includes five phases, namely: (1) preliminary investigation, (2) design, (3) the realization/construction, (4) test, evaluation, and revision, and (5) implementation. The place of research in elementary Al Fatah Wiyung Surabaya, with the object of research is the class VB totaling 19 students as a class field trials, and the VA grade students who are 25 students as a class implementation. Trial design uses one group pretest posttest design by using descriptive analysis of quantitative and qualitative descriptive. The research instrument consists of a sheet validation learning device, the observation sheet teachers' ability to manage learning, observation sheet activities into learning, and pieces of student questionnaire responses. The data collection was done by using observation, testing, documentation methods, and the student questionnaire responses.

The quality of teaching instumets development is characterized by: 1). The validity of the study is valid with an average range of total validity $3.4 \leq R T V \leq 3.7$ coefficient validity tests about $\geq 0.4$ reached sufficient criteria, test reliability is $\alpha=0.73$ and a moderate degree. 2) Practicality learning device shown by the results of the teacher's ability to manage learning obtained a mean score of 3.6 has criteriary well. 3) The effectiveness of the learning device includes: a) The results of students in cognitive learning students achieve mastery in classical amounted to $78.9 \%$ of the average grade is $3.28 / \mathrm{B}+$. b) The results of students in the affective achieve mastery learning students in classical by $89.5 \%$ and predicated either end. c) The results of students in the psychomotor domain of learning students achieve mastery in classical amounted to $94.7 \%$ and the achievement of optimum grade is $3.61 / A-$. d) When the learning activities of students in accordance with the criteria defined by the tolerance limit of $10 \%$. e) Questionnaire response of students to the learning instruments developed reached a percentage of $83.5 \%$.

The test results on the effectiveness of the learning device implementation class is shown through: 1) Score average teacher's ability to manage learning during the three meetings was 3.63 and general assesments very good. 2) The results of students in cognitive learning students achieve mastery in classical amounted to $76.0 \%$ of the average grade is 2.95/B. 3) The results of students in the affective achieve mastery learning students classically by $100 \%$ and predicated either end. 4) The results of students in the psychomotor domain of learning students achieve mastery in classical amounted to $96.0 \%$ and the achievement of optimum grade is $3.45 / B+.5$ ) When the learning activities of students in accordance with the criteria defined by the tolerance limit of 10\%. 6) Questionnaire response of students to the learning instruments developed reached $84.0 \%$ percentage.

Based on the results of field testing and implementation, it can be concluded that the study produced by the cooperative learning model investigation of this group of devices that meet the criteria of decent quality used that validity, practicality, and effectiveness. In addition to testing the effectiveness of learning, learning outcomes developed device can increase student learning outcomes for the better

Keywords: learning device, cooperative learning model, the investigation group, similarity, symmetry

\section{PENDAHULUAN}

Matematika merupakan salah satu mata pelajaran yang memberikan kontribusi positif untuk tercapainya masyarakat cerdas dan bermartabat (Suminarsih, 2007:1). Setiap individu dapat menumbuhkan kemampuan diri berfikir tajam, menggunakan logika dan rasional melalui belajar matematika. Dengan berpikir logis, seorang individu akan mampu membedakan secara cermat, kritis terhadap setiap kejadian sesuai dengan ilmu pengetahuan.

Dalam Badan Standar Nasional Pendidikan (Depdiknas,2006) diuraikan bahwa, pelajaran matematika perlu diberikan kepada semua peserta didik mulai dari sekolah dasar untuk membekali kemampuan berpikir logis, analitis, sistematis, kritis, kreatif, serta kemampuan bekerjasama. Kompetensi tersebut diperlukan, supaya peserta didik memiliki kemampuan untuk memperoleh, mengelola, dan memanfaatkan informasi untuk bertahan hidup pada keadaan yang selalu berubah, dan kompetitif.
Untuk mencapai kompetensi matematika yang ditetapkan perlu indikator ketercapaian tujuan pembelajaran. Tujuan pembelajaran matematika di sekolah tertuang dalam Standar Isi KTSP 2006 sebagai berikut:

a) Memahami konsep matematika, menjelaskan keterkaitan antar konsep dan mengaplikasikan konsep atau algoritma, secara luas, akurat, efisien, dan tepat dalam pemecahan masalah;

b) Menggunakan pemahaman pada pola dan sifat, melakukan manipulasi matematika dalam membuat generalisasi, menyusun bukti, atau menjelaskan gagasan dan pernyataan matematika;

c) Memecahkan masalah yang meliputi kemampuan memahami masalah, merancang model matematika, menyelesaikan model dan menafsirkan solusi yang diperoleh;

d) Mengkomunikasikan gagasan dengan simbol, tabel, diagram, atau media lain untuk memperjelas keadaan atau masalah;

e) Memiliki sikap menghargai kegunaan matematika dalam kehidupan, yaitu memiliki 
rasa ingin tahu, perhatian dan minat dalam mempelajari matematika, serta sikap ulet dan percaya diri dalam pemecahan masalah (Depdiknas, 2006).

Berdasarkan uraian tersebut disimpulkan bahwa, pembelajaran matematika tidak terbatas pada penguasaan fakta, prosedur, dan pemahaman konsep, namun juga kemampuan proses matematika siswa seperti pemecahan masalah, penalaran, dan komunikasi matematika. Semua harus saling menunjang, sehingga siswa dapat menguasai matematika secara utuh.

Pergeseran pendidikan dari pengajaran (teaching) menjadi pembelajaran (learning) tentu membawa perubahan pada pola-pola baru kegiatan pembelajaran. Pembelajaran berpusat pada siswa harus lebih dikembangkan. Namun kenyataanya, hal tersebut belum sepenuhnya terlaksana secara optimal. Pembelajaran matematika dengan peran guru dominan, pendekatan yang menekankan latihan dan pengerjaan soal, disertai hafalan rumus sebagian besar masih dilakukan oleh guru.

Menurut teori Ausubel guru harus dapat mengembangkan potensi siswa melalui proses belajar bermakna. Kebermaknaan tersebut dapat diperoleh melalui aktivitas siswa yang dilibatkan langsung dalam kegiatan pembelajaran. Siswa secara aktif mengenal konsep, struktur, serta memahami materi yang harus dikuasai (Arifin, 2010:71). Artinya, siswa melakukan aktivitas belajar untuk membangun pengetahuan sendiri dengan berusaha dan mencari melalui pengalaman, penyelidikan atau eksplorasi agar belajar lebih dipahami.

Berdasarkan hal tersebut, perlu suatu kegiatan pembelajaran yang mendorong siswa mengorganisasi pengalaman sendiri menjadi pengetahuan bermakna. Menciptakan pembelajaran bersifat konstruktivis, yang memungkinkan keterlibatan siswa menggali kemampuan dan potensi. Guru tidak melakukan doktrinasi pengetahuan, namun mendorong siswa menemukan dan mengeksplorasi pengetahuan dengan apa yang telah diketahui dan dipelajari sendiri. Inti pembelajarannya adalah ide siswa harus menjadikan informasi itu miliknya sendiri (Nur dan Wikandari, 2008:2).

Salah satu alternatif pembelajaran yang dapat menjembatani siswa menemukan konsep matematika sendiri adalah kegiatan investigasi yaitu pembelajaran yang memberikan kesempatan luas kepada siswa menemukan konsep matematika yang akan dipelajari secara mandiri. Menurut Kissane (dalam Shadiq: 2007), "A person given a fish is fed for a day. A person taught to fish is fed for life". Dengan kegiatan penyelidikan, para siswa dilatih, tidak hanya menerima sesuatu yang sudah jadi layaknya diberi seekor ikan yang dapat dan tinggal dimakan selama sehari saja, namun, dilatih seperti layaknya belajar cara menangkap ikan tersebut sehingga bisa makan ikan selama hidupnya. Ini menunjukkan bahwa, dengan menyelidiki sendiri diharapkan konsep pelajaran yang ditemukan siswa lebih bermakna daripada konsep yang langsung diberikan oleh guru.

Penelitian Etherington,

merekomendasikan "Teachers are to engage their school students in the process of investigating, the process of designing and making and the use of technology". Para guru perlu melibatkan para siswa sekolah mereka dalam proses penyelidikan, proses merancang dan membuat dan penggunaan teknologi.“...Teachers are to engage school students in the process of designing and making which requires learners to use resources to assemble or construct products, systems or environments...". Guru perlu melibatkan para siswa sekolah dalam proses merancang dan membuat, yang mengharuskan peserta didik menggunakan sumber daya untuk merakit atau membangun produk, sistem atau lingkungan.

Masih berkenaan dengan kegiatan investigasi, beberapa hasil penelitian sebelumnya pernah dilakukan antara lain menurut Hariyanti (2010) menyatakan bahwa, pembelajaran menggunakan investigasi kelompok pada pembelajaran kongruensi dan kesebangunan sekurang-kurangnya membuat kemampuan penalaran matematika siswa mencapai kategori baik, karena meningkat dari rata-rata 55,64\% menjadi 74,61\%. Hermawan (2012) dalam penelitiannya mengenai kemampuan memecahkan masalah dengan penerapan model pembelajaran investigasi kelompok pada siswa sekolah dasar terdapat rerata persentase skor siswa $60,57 \%$ dan 13 orang $(37,14 \%)$ dari 35 orang siswa mencapai kategori baik mendapatkan skor $\geq 70$.

Merujuk pada karakteristik serta hasil penelitian sebelumnya disimpulkan bahwa, kegiatan investigasi matematika mampu menjadikan siswa lebih baik dalam mengkonstruksi pengetahuan dan kemampuan proses matematika sendiri. Siswa akan terdorong melakukan kegiatan berpikir matematis, mencari serta menemukan 
konsep dan aturan matematika dengan kegiatan yang lebih mandiri. Untuk mengimplementasikan kegiatan belajar dengan penyelidikan dibutuhkan perangkat pembelajaran. Namun sejauh pengetahuan peneliti, masih jarang dijumpai perangkat pembelajaran yang dikembangkan dengan kegiatan investigasi untuk siswa sekolah dasar. Bahkan pengalaman peneliti selama mengajar di sekolah belum pernah mengembangkan perangkat pembelajaran. Harapan peneliti, dengan dikembangkannya perangkat pembelajaran tersebut, dapat membantu meningkatkan hasil belajar siswa untuk mencapai tujuan pembelajaran yang telah ditetapkan.

Aspek matematika yang diajarkan di Sekolah Dasar dengan Kurikulum Tingkat Satuan Pendidikan (KTSP) tahun 2006 diantaranya geometri dan pengukuran. Salah satu Standar Kompetensi (SK) pada geometri dan pengukuran di kelas V SD adalah memahami sifat-sifat bangun dan hubungan antar bangun, dengan Kompetensi Dasar (KD) yaitu menyelidiki sifat-sifat kesebangunan dan simetri. Materi ini cocok disajikan dengan kegiatan investigasi yang memberikan ruang kepada siswa mengeksplorasi pengetahuan yang dimiliki.

\section{METODE PENELITIAN}

Penelitian ini adalah penelitian pengembangan. Perangkat pembelajaran yang dikembangkan meliputi rencana pelaksanaan pembelajaran (RPP), lembar kerja siswa (LKS), instrumen penilaian meliputi tes hasil belajar (THB), lembar penilaian afektif, dan lembar penilaian psikomotor. Perangkat yang dikembangkan menggunakan model pembelajaran kooperatif tipe investigasi kelompok pada materi kesebangunan dan simetri di kelas V sekolah dasar.

Pengembangan perangkat pembelajaran mengikuti prosedur pengembangan Plomp yang meliputi lima fase, yaitu: fase investigasi awal, fase desain, realisasi/ konstruksi, fase tes, evaluasi, dan revisi, dan fase implementasi. Prosedur pada setiap fase sebagai berikut:

1. Fase Investigasi Awal (Preliminary Investigation)

Fase ini difokuskan pada kegiatan mengidentifikasi informasi, menganalisis informasi terhadap situasi permasalahan, dan menganalisis kurikulum pada pembelajaran matematika di sekolah. Hasil analisis kemudian diidentifikasi dan dilakukan kegiatan lanjutan.
2. Fase Perancangan (Design)

Fase ini aktivitas yang dilakukan merancang perangkat pembelajaran matematika menggunakan model pembelajaran kooperatif tipe investigasi kelompok dan instrumen penelitian.

3. Fase Realisasi/Konstruksi

(Realization/Construction)

Pada fase realisasi ini dibuat perangkat pembelajaran matematika menggunakan pembelajaran kooperatif tipe investigasi kelompok dan realisasi instrumen penelitian.

4. Fase Tes, Evaluasi dan Revisi (Test, Evaluation and Revision)

Pada pelaksanaan fase ini akan dilakukan 3 tahap kegiatan, yaitu validasi perangkat pembelajaran, uji keterbacaan, dan uji coba perangkat pembelajaran.

5. Fase Implementasi (Implementation)

Hasil prototipe final perangkat pembelajaran yang diterima pada fase 4 selanjutnya diujicobakan pada kelas yang ditetapkan sebagai kelas implementasi.

Rancangan pelaksanaan penelitian ini adalah one-group pre test-post test design. Yaitu memberikan suatu perlakuan tertentu kepada satu kelompok subjek saja tanpa ada pembanding (Sugiyono, 2008:111). Guru memberikan pre test untuk mengetahui hasil belajar siswa sebelum diterapkan pembelajaran menggunakan model pembelajaran kooperatif tipe investigasi kelompok. Selanjutnya diberikan post test untuk mengetahui hasil belajar sesudah diterapkan pembelajaran dengan menggunakan model pembelajaran kooperatif tipe investigasi kelompok. Uraian rancangan penelitian tersebut digambarkan sebagai berikut:

\begin{tabular}{|l|l|l|}
\hline $\mathbf{O}_{1}$ & $\mathbf{X}$ & $\mathbf{O}_{2}$ \\
\hline
\end{tabular}

Gambar 1. Rancangan One-Group Pre Test-Post Test Design

Keterangan:

$\mathrm{O}_{1}$ : Pre test digunakan untuk mengetahui hasil belajar siswa sebelum diterapkan pembelajaran matematika menggunakan pembelajaran kooperatif tipe investigasi kelompok

$\mathrm{X}$ : Perlakuan kepada siswa dengan memberikan pembelajaran matematika menggunakan pembelajaran kooperatif tipe investigasi kelompok 
$\mathrm{O}_{2}$ : Post test digunakan untuk mengetahui hasil belajar siswa sesudah diterapkan pembelajaran matematika menggunakan pembelajaran kooperatif tipe investigasi kelompok

Subjek penelitian perangkat pembelajaran adalah siswa kelas V SD Al Fatah Wiyung Surabaya tahun pelajaran 2015-2016. Kelas tersebut terdiri dari 44 siswa. Sampel penelitian ini adalah siswa kelas VB sebagai kelas ujicoba lapangan berjumlah 19 siswa, sedangkan kelas VA sebagai kelas implementasi sebanyak 25 siswa. Penentuan sampel kelas penelitian berdasarkan masukan dari guru mitra setempat, bahwa pembagian kelas siswa merata dengan kemampuan yang heterogen.

Metode pengumpulan data penelitian ini dilakukan dengan teknik observasi, tes, metode dokumentasi, dan pemberian angket respon siswa. Penelitian ini dilakukan di SD Al Fatah Wiyung Surabaya pada periode semester gasal tahun ajaran 2015/2016. Kegiatan pembelajaran dilakukan 12 kali pertemuan.

\section{HASIL DAN PEMBAHASAN}

Kegiatan penelitian ini berhasil mengembangkan perangkat pembelajaran yang berkualitas menggunakan model pembelajaran kooperatif tipe investigasi kelompok pada materi kesebangunan dan simetri di kelas V SD. Standar kompetensi materi adalah memahami sifat-sifat bangun dan hubungan antar bangun dengan kompetensi dasar menyelidiki sifat-sifat kesebangunan dan simetri. Perangkat pembelajaran yang berhasil dikembangkan adalah: 1) rencana pelaksanaan pembelajaran (RPP), 2) lembar kegiatan siswa (LKS), dan 3) instrumen penilaian yang meliputi tes hasil belajar (THB), lembar penilaian afektif, dan lembar penilaian psikomotor.

Kriteria yang digunakan untuk menentukan kelayakan hasil pengembangan perangkat pembelajaran yang telah dihasilkan didasarkan kriteria Nieveen (1997). Kriteria tersebut menilai kualitas perangkat pembelajaran berdasarkan aspek kevalidan (validity) kepraktisan (practicality dan keefektifan (efectiveness).

Sebelum diperoleh bentuk prototipe final, terlebih dahulu dilakukan validasi terhadap perangkat pembelajaran oleh para pakar yang terdiri dari 2 orang dosen yang berkompeten pada bidang keahlian matematika dan pembelajaran matematika di sekolah dasar, dan 2 orang guru yang berkompeten sebagai guru kelas $\mathrm{V}$ dan guru bahasa Indonesia.

Perangkat yang dikembangkan dalam penelitian ini telah memenuhi kevalidan baik aspek isi maupun konstruknya karena sesuai dengan prinsip-prinsip dan karakteristik pembelajaran matematika menggunakan model pembelajaran kooperatif tipe investigasi kelompok. Rangkuman hasil validasi perangkat pembelajaran oleh empat orang pakar disajikan dalam tabel berikut.

Tabel 1. Rangkuman Hasil Validasi Perangkat Pembelajaran

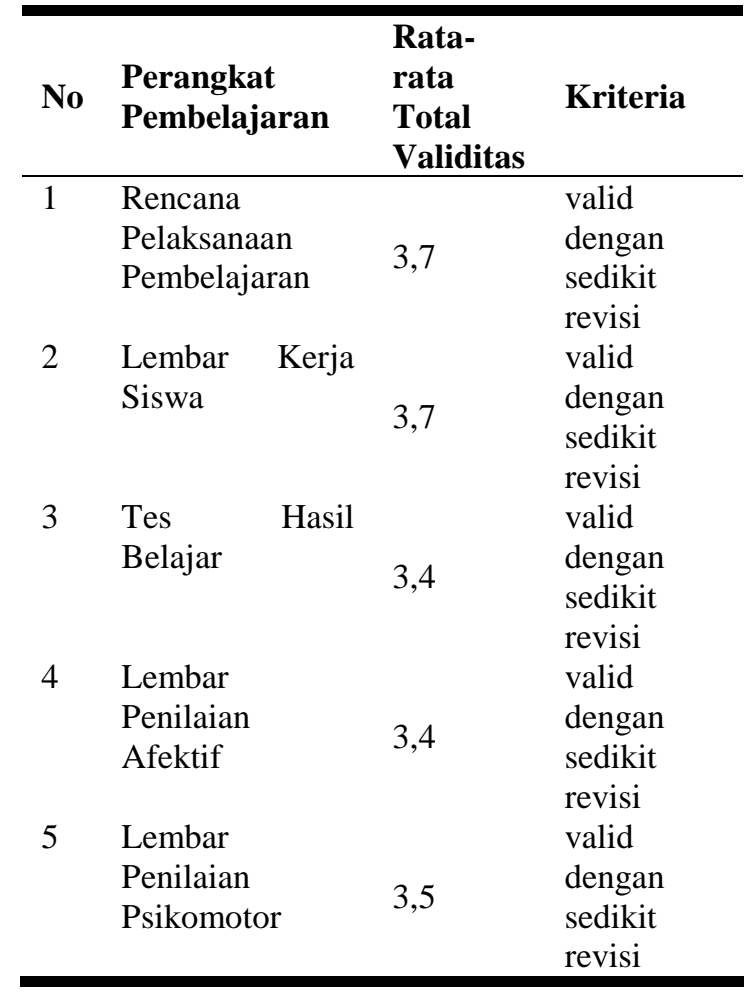

Berdasarkan data tabel 1 disimpulkan bahwa validasi para ahli terhadap konstruk dan isi perangkat pembelajaran matematika pada materi kesebangunan dan simetri secara umum memenuhi kriteria valid dengan sedikit revisi dan bisa diterapkan pada rencana lanjutan.

Kegiatan berikutnya adalah dilakukan uji keterbacaan terhadap perangkat pembelajaran yang telah divalidasi (prototipe 2). Uji keterbacaan ini untuk memperoleh informasi perangkat pembelajaran dapat terbaca jelas dan dipahami sehingga dapat digunakan pada kelas ujicoba lapangan. Hasil uji keterbacaan digunakan untuk merevisi prototipe 2 menjadi prototipe 3 . Peneliti memilih 6 orang siswa dari kelas VA dengan kemampuan yang berbeda. Siswa yang telah ditunjuk diminta membaca lembar kerja siswa dan tes hasil belajar kemudian menandai kata-kata atau 
kalimat yang tidak dipahami. Data yang diperoleh menunjukkan bahwa para siswa umumnya menyatakan bahasa yang digunakan pada LKS dan THB dapat dipahami dengan baik.

Perangkat pembelajaran yang diperoleh dari hasil validasi dan uji keterbacaan ini (prototipe 3) selanjutnya diujicobakan pada siswa kelas VB SD Al Fatah Wiyung Surabaya tahun pelajaran 20152016 yang berjumlah 19 siswa. Ujicoba dilaksanakan selama 6 kali pertemuan yang diawali dengan pre test dan diakhiri dengan post test serta pemberian angket respon siswa.

Pada pelaksanaan ujicoba ini yang bertindak sebagai pengajar adalah peneliti. Sedangkan sebagai pengamat melibatkan 2 orang guru. Pengamatan dilakukan selama 3 kali pertemuan pembelajaran. Seorang pengamat melakukan pengamatan terhadap guru dalam mengelola pembelajaran, dan seorang pengamat yang lain melakukan pengamatan terhadap aktivitas siswa. Siswa yang diamati ada 6 siswa yaitu 2 siswa berkemampuan tinggi, 2 siswa berkemampuan sedang, dan 2 siswa berkemampuan rendah yang merepresentasikan kemampuan akademik siswa seluruh kelas. Pemilihan kelompok ini didasarkan pada perbedaan kemampuan akademik yang diperoleh dari nilai rata-rata rapot, hasil pre test, serta jenis kelamin.

Adapun data-data yang dikumpulkan pada kelas ujicoba lapangan ini meliputi:

1. Kemampuan guru mengelola pembelajaran

Pengamatan terhadap kemampuan guru mengelola pembelajaran diamati menggunakan lembar pengamatan oleh seorang pengamat. Pengamatan dilakukan sebanyak 3 kali pertemuan dalam pembelajaran. Analisis terhadap pengamatan kemampuan guru dalam mengelola pembelajaran dilakukan dengan menentukan rata-rata setiap aspek pengamatan pada komponen pembelajaran. Hasil analisis terhadap kemampuan guru mengelola pembelajaran ditampilkan dalam tabel berikut.

Tabel 2. Rekapitulasi Rata-rata Kemampuan Guru Mengelola Pembelajaran pada Kelas Ujicoba Lapangan

\begin{tabular}{llllll}
\hline No & $\begin{array}{l}\text { Aspek } \\
\text { Penilaian }\end{array}$ & P-1 & $\mathbf{P - 2}$ & $\mathbf{P - 3}$ & $\begin{array}{l}\text { Rata- } \\
\text { rata } \\
\text { Tiap } \\
\text { Aspek }\end{array}$ \\
\hline 1. & Pendahuluan & 3,8 & 4,0 & 3,8 & 3,8 \\
2. & Kegiatan Inti & 3,3 & 3,3 & 3,2 & 3,3 \\
3. & $\begin{array}{l}\text { Penutup } \\
\text { 4. }\end{array}$ & Pengelolaan & 4,0 & 4,0 & 4,0 \\
waktu dan & 3,0 & 4,0 & 3,3 & 3,4 \\
\hline
\end{tabular}

\begin{tabular}{|c|c|c|}
\hline suasana kelas & & \\
\hline Rata-rata akhir & & 3,63 \\
\hline $\begin{array}{l}\text { Penilaian Tingkat } \\
\text { (TKG) }\end{array}$ & Kemampuan Guru & $\begin{array}{l}\text { sangat } \\
\text { baik }\end{array}$ \\
\hline
\end{tabular}

Pembahasan mengenai kemampuan guru mengelola pembelajaran ini bahwa aktivitas guru tidak mendominasi di kelas. Peran guru lebih menjadi narasumber dan fasilitator yang terlibat dalam proses kelompok, membantu siswa dalam merumuskan rencana, bertindak, dan mengatur kelompok. Intinya peran guru sebagai seorang konselor akademik (Joyce, dkk, 2011:32) bisa dilaksanakan dengan baik. Aktivitas guru ini sejalan dengan salah satu prinsip teori Vygotsky dimana guru memberikan perancahan (scaffolding) terhadap siswa dalam kegiatan penyelidikan. Guru memberikan dukungan kepada siswa pada tahaptahap awal pembelajaran kemudian menghilangkan dukungan dan meminta siswa tersebut memikul tanggung jawab yang makin besar begitu ia sanggup (Santrock, 2011:63). Kesimpulan umum seluruh aktivitas guru dalam mengelola pembelajaran sesuai dengan rangkaian kegiatan yang termuat dalam RPP selama 3 kali pertemuan diperoleh skor rata-rata 3,63 dengan kategori sangat baik. Oleh karena itu hasil pengembangan Rencana Pelaksanaan Pembelajaran (RPP) menggunakan model pembelajaran kooperatif tipe investigasi kelompok pada materi kesebangunan dan simetri ini memenuhi kriteria kepraktisan suatu perangkat dan layak digunakan dalam melaksanakan pembelajaran.

2. Hasil belajar siswa

Berikut ini adalah tabel ringkasan hasil belajar siswa pada ranah kognitif, afektif, dan psikomotor pada kelas ujicoba lapangan

Tabel 3. Rekapitulasi Hasil Belajar Siswa pada Kelas Ujicoba Lapangan

\begin{tabular}{ll}
$\begin{array}{l}\text { Komponen } \\
\text { Data }\end{array}$ & Pencapaian \\
\hline Tes Hasil & - Validitas butir tes \\
Belajar (THB) & Koefisien validitas tiap butir \\
& tes $\geq 0,4$ berkategori cukup. \\
& - Koefisien reliabilitas $\alpha=$ \\
& $0,73$. \\
- Derajat reliabilitas : sedang & - Ketuntasan belajar individu \\
& Jumlah siswa tuntas : 15 \\
& siswa \\
& Jumlah siswa tidak tuntas: 4 \\
& siswa \\
& - Ketuntasan belajar klasikal: \\
& $78,9 \%$ \\
\hline
\end{tabular}


Data pada Tabel 3 memberikan informasi bahwa tes hasil belajar memenuhi kriteria kevalidan dengan koefisien validitas tiap butir tes $\geq 0,4$ dan berkategori cukup. Sedangkan reliabilitas tes $\alpha=$ 0,73 dan berderajat sedang. Hasil belajar siswa pada ranah kognitif menunjukkan bahwa ketuntasan hasil belajar klasikal setelah diberikan post test sebesar 78,9\%. Artinya sebanyak 15 siswa mencapai ketuntasan belajar secara individu dan 4 siswa tidak mencapai ketuntasan belajar secara individu dengan rata-rata kelas adalah 3,28. Ini berarti ketuntasan belajar siswa secara klasikal pada kelas ujicoba lapangan terlampaui 3,9\% dari kriteria batas minimal yaitu 75\%. Hasil analisis ketuntasan belajar siswa secara individu pada penilaian afektif bahwa terdapat 17 siswa yang memiliki modus ketuntasan kompetensi berpredikat baik dan 2 siswa berpredikat cukup. Adapun hasil ketuntasan belajar siswa secara klasikal mencapai $89,5 \%$. Hasil analisis terhadap penilaian psikomotor secara keseluruhan diperoleh rerata akhir kelas adalah 3,61. Analisis terhadap ketuntasan belajar siswa secara individu pada penilaian psikomotor ini bahwa terdapat 18 siswa yang memiliki capaian optimum kompetensi $\geq 2,80$ dari 19 siswa, dan hasil ketuntasan belajar siswa secara klasikal mencapai $94,7 \%$.

Kesimpulan akhir hasil analisis penilaian hasil belajar siswa menggunakan model pembelajaran kooperatif tipe investigasi kelompok pada materi kesebangunan dan simetri di kelas V adalah tercapai. Artinya penilaian hasil belajar siswa ini memenuhi kriteria keefektifan perangkat pembelajaran.

3. Aktivitas siswa dalam pembelajaran

Aktivitas siswa merupakan kegiatan siswa selama proses pembelajaran menggunakan perangkat pembelajaran yang telah dikembangkan sebagai acuan. Selama pembelajaran berlangsung, aktivitas siswa diamati oleh seorang pengamat selama 3 kali sesuai dengan jumlah pertemuan yang dilaksanakan dalam pembelajaran. Pengamatan dilakukan terhadap aktivitas yang dilakukan siswa setiap 5 menit sekali. Visualisasi aktivitas siswa dalam pembelajaran tersebut dapat disajikan melalui gambar diagram batang berikut:

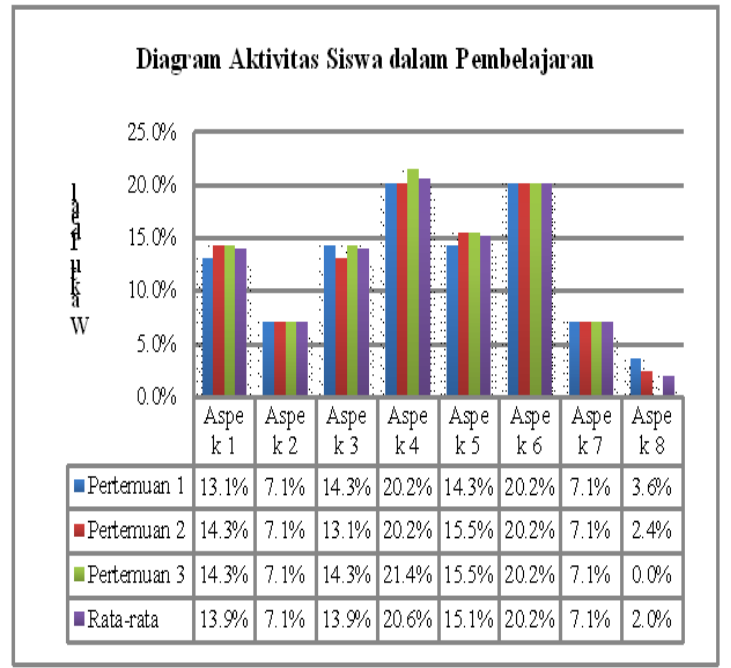

Gambar 2. Diagram Batang Hasil Pengamatan Aktivitas Siswa pada Kelas Ujicoba Lapangan

Aktivitas siswa dalam penelitian ini menunjukkan bahwa, persentase aktivitas siswa selama kegiatan pembelajaran dalam pertemuan 1 , pertemuan 2, dan pertemuan 3 menggunakan pembelajaran kooperatif tipe inve stigasi kelompok secara rata-rata memenuhi kriteria baik sesuai batasan kriteria keefektifan yang telah ditetapkan. Beberapa aktivitas siswa yang perlu dikelola tepat adalah aktivitas menyiapkan laporan akhir (persentase rata-rata akhir $15,1 \%$ dengan kriteria waktu ideal 14,3\%) dan perilaku siswa yang tidak relevan selama pembelajaran (persentase rata-rata akhir 2,0\% dengan kriteria waktu ideal 0,0\%). Selain itu diperoleh bahwa rata-rata aktivitas siswa yang dominan yaitu berdiskusi dengan teman untuk melaksanakan kegiatan investigasi (Aspek 4) mencapai 20,6\% dan mempresentasikan laporan akhir kegiatan penyelidikan (Aspek 6) mencapai $20,2 \%$. 
Pembahasan mengenai aktivitas-aktivitas siswa yang diamati pada pembelajaran menggunakan model pembelajaran kooperatif tipe investigasi kelompok pada ujicoba lapangan diuraikan sebagai berikut:

a) Mendengarkan/memperhatikan penjelasan guru Aktivitas siswa pada kegiatan ini adalah mendengarkan semua penjelasan guru mengenai hal-hal yang akan dilakukan dalam pembelajaran kooperatif dengan kegiatan penyelidikan. Antusias siswa untuk mengikuti pembelajaran sangat besar. Hal ini ditunjukkan dengan banyaknya pertanyaanpertanyaan yang diajukan oleh siswa terhadap guru sebelum kegiatan penyelidikan dilaksanakan. Adanya semangat dan ketertarikan ini mencerminkan rasa ingin tahu, rasa tanggung jawab, dan rasa kebersamaan siswa untuk memecahkan persoalan dalam kegiatan pembelajaran.

b) Membaca, memahami materi, dan mengidentifikasi masalah dalam LKS.

Aktivitas siswa berikutnya adalah bekerja dalam kelompok. Bersama anggota tim yang lain dalam kelompok, siswa berbagi tugas, memahami materi ajar dan berdiskusi tentang daftar pertanyaan-pertanyaan yang telah disusun sebelumnya seperti yang ditunjukkan pada gambar berikut.

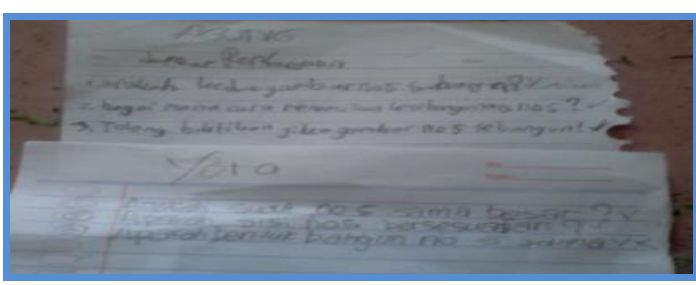

Gambar 3. Contoh Daftar Pertanyaan yang Diajukan Anggota Kelompok Siswa Tentang Penyelidikan.

Aktivitas siswa ini menunjukkan bahwa, model pembelajaran kooperatif tipe investigasi kelompok dapat mengembangkan kemampuan siswa mengungkapkan ide atau gagasan dengan kata-kata secara verbal dan membandingkannya dengan ide-ide siswa lain. Hal ini sejalan dengan salah satu prinsip teori Vygotsky (Nur dan Wikandari, 2008:4) mengenai hakekat sosio cultural, bahwa interaksi sosial dengan teman lain memacu terbentuknya ide baru dan memperkaya perkembangan intelektual siswa.

c) Merencanakan tugas dalam kelompok.

Aktivitas siswa pada kegiatan pembelajaran ini adalah setiap anggota dalam kelompok berdiskusi merencanakan langkah-langkah yang harus dilakukan untuk kegiatan penyelidikan. Akhir kegiatan ini adalah menentukan rumusan masalah serta hipotesis. Analisa terhadap aktivitas ini bahwa siswa mampu bekerjasama dalam mengerjakan tugas kelompok, saling bertukar pikiran, saling menghargai pendapat teman, mengemukakan pendapat untuk menemukan berbagai alternatif pemecahan masalah pada materi yang dipelajari. Aktivitas siswa ini sesuai dengan salah satu prinsip dari enam konsep kunci pembelajaran kooperatif menurut Spencer Kagan (1994) yaitu prinsip (1) positive interdependence dimana saling ketergantungan positif yang terkuat akan diraih bila prestasi kelompok memberikan kontribusinya terhadap tim, (2) individual accountability yaitu setiap anggota kelompok bertanggung jawab meningkatkan kecakapan dan kinerja anggota kelompok yang lain, atau meningkatkan kinerja kelompok yang lain, (3) equal participation yaitu siswa belajar karena interaksi dengan materi pembelajaran dan partisipasi yang setara (4) simultaneus interaction yaitu interaksi antar siswa harus selalu dilaksanakan dan berlangsung serentak. d) Berdiskusi dengan teman untuk melaksanakan kegiatan investigasi.

Aktivitas siswa pada kegiatan ini adalah siswa berdiskusi dengan teman sekelompok memecahkan masalah penyelidikan seperti gambar berikut.

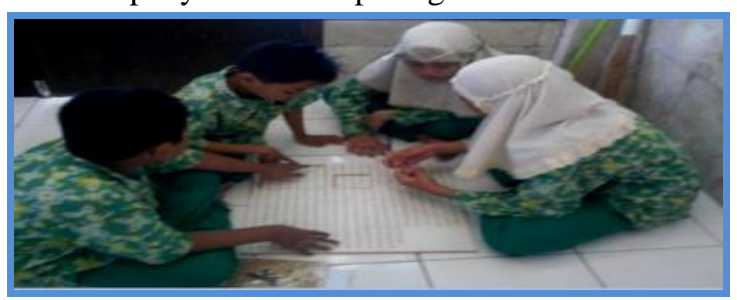

Gambar 4. Aktivitas Siswa Dalam Satu Kelompok Sedang Melakukan Investigasi

Dalam kegiatan investigasi ini siswa melakukan aktivitas belajar untuk membangun pengetahuan sendiri dan berusaha mencari melalui pengalaman, penyelidikan atau eksplorasi agar proses belajar lebih dipahami. Siswa sangat antusias mengikuti proses pembelajaran melalui penyelidikan dari berbagai sumber salah satunya menggunakan media yang dibuat (geoboard, media bangun datar), saling berdiskusi dan aktif berargumentasi bersama anggota kelompoknya sesuai dengan tujuan yang diharapkan. Aktivitas ini memunculkan sebuah interaksi yang baik antara siswa dengan siswa, siswa dengan guru dan siswa dengan sumber belajar maupun lingkungan. Selain itu siswa juga terlatih berkomunikasi, menyampaikan pendapat, mengembangkan 
keterampilan sosial seperti kerjasama dan menerima perbedaan.

e) Menyiapkan laporan akhir.

Aktivitas siswa pada kegiatan pembelajaran ini adalah setiap kelompok menyusun laporan akhir hasil penyelidikan. Hasil-hasil kerja siswa disusun secara rapi sesuai dengan langkah-langkah penyelidikan yang terlampir dalam LKS. Gambar ini merupakan contoh laporan hasil penyelidikan yang telah dilakukan oleh satu kelompok siswa.

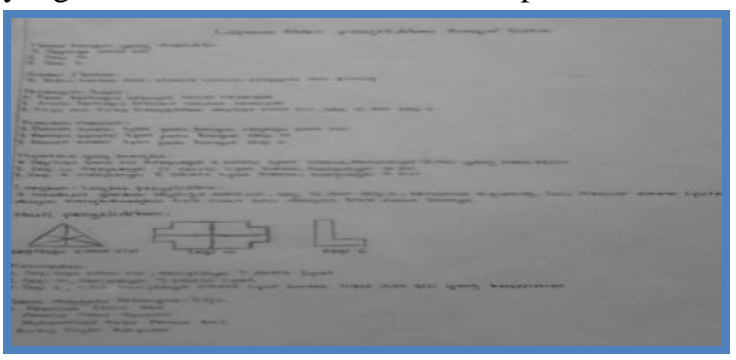

Gambar 5. Hasil Laporan Akhir Penyelidikan

f) Mempresentasikan hasil laporan akhir.

Setelah laporan akhir penyelidikan tersusun, maka setiap kelompok siswa mempresentasikan hasil kerjanya di depan kelas. Aktivitas yang muncul antara lain siswa berbagi peran dalam kegiatan presentasi dan berpartisipasi dalam kegiatan diskusi dengan mengajukan pertanyaan. Hasil diskusi mengenai aktivitas siswa dalam kegiatan presentasi ini bahwa siswa mulai terbiasa melakukan diskusi kelompok, seluruh anggota kelompok telah berperan/terlibat langsung dalam penggunaan media, saling bekerjasama dalam mengemban tugas kelompok, terampil menggunakan media sebagai sumber belajar, serta aktif dalam bertanya atau memberi tanggapan.

g) Mengevaluasi pembelajaran dan hasil kegiatan presentasi.

Aktivitas siswa dalam pembelajaran ini adalah mengevaluasi pembelajaran bersama guru mengenai kendala-kendala dalam melakukan penyelidikan dan presentasi. Selain itu adanya review terhadap pembelajaran menjadikan pembelajaran lebih bermakna. Sejalan dengan teori belajar yang dikemukakan oleh Ausubel tentang belajar akan lebih bermakna jika siswa berusaha menghubungkan informasi-informasi baru ke struktur pengetahuan mereka, sehingga ingatan siswa akan lebih kuat.

h) Perilaku siswa tidak relevan dengan pembelajaran

Beberapa aktivitas yang tidak relevan muncul dalam kegiatan ini diantaranya beberapa siswa bersikap pasif dalam melakukan tugas kelompok, melakukan aktivitas lain misalnya menggambar yang tidak sesuai dengan pembelajaran, tidak bekerjasama dengan teman satu tim, dan mengganggu aktivitas anggota kelompok sendiri atau kelompok lain. Peran guru dalam pengelolaan perlu ditingkatkan lebih baik sehingga pelaksanaan pembelajaran lebih efektif.

Diskusi berdasarkan aktivitas-aktivitas yang telah dilakukan siswa menggunakan model pembelajaran koperatif tipe investigasi kelompok pada ujicoba lapangan ini selaras dengan makna pembelajaran kooperatif menurut Ibrahim (2000:6) bahwa (a) siswa dalam kelompok haruslah beranggapan bahwa mereka sehidup sepenanggungan bersama, (b) siswa bertanggung jawab atas segala sesuatu di dalam kelompok, seperti milik mereka sendiri, (c) siswa harus melihat bahwa semua anggota di dalam kelompok memiliki tujuan yang sama, (d) siswa harus membagi tugas dan bertanggung jawab yang sama diantara anggota kelompok yang sama, (e) siswa akan dikenakan evaluasi atau diberikan hadiah atau penghargaan yang juga akan dikenakan oleh anggota kelompok, (f) siswa berbagi kepemimpinan dan mereka membutuhkan keterampilan untuk belajar bersama selama proses belajarnya, (g) siswa akan diminta mempertanggungjawabkan secara individual materi yang ditangani dalam kelompok kooperatif.

Kesimpulan akhir dari aktivitas siswa selama pembelajaran menggunakan model pembelajaran kooperatif tipe investigasi kelompok pada materi kesebangunan dan simetri di kelas $\mathrm{V}$ sekolah dasar memenuhi kriteria keefektifan perangkat pembelajaran dan layak digunakan lebih lanjut, karena memenuhi kriteria keefektifan batas waktu ideal dengan toleransi $10 \%$.

\section{Angket respon siswa}

Angket respon siswa digunakan untuk mengetahui respon, minat, pendapat dan penilaian siswa terhadap pelaksanaan kegiatan belajar mengajar. Angket respon siswa diberikan kepada siswa setelah pembelajaran. Hasil angket dianalisis menggunakan statistik deskriptif dalam bentuk persentase dan dikelompokkan untuk setiap indikator. Hasil analisis berdasarkan angket diperoleh persentase rata-rata keseluruhan $\geq 80 \%$ yaitu sebesar $83,5 \%$ merespon positif terhadap perangkat pembelajaran dan kegiatan pembelajaran yang telah dilangsungkan. Hal ini sesuai yang diungkapkan oleh Nur dan Wikandari (2008:30) bahwa ketertarikan dan keberminatan siswa 
terhadap pelajaran dan metode pembelajaran dapat meningkatkan motivasi untuk belajar.

Berdasarkan uraian hasil pengembangan perangkat pembelajaran serta didasarkan pada kriteria pengembangan perangkat pembelajaran yang berkualitas, maka hasil perolehan pencapaian pengembangan perangkat menggunakan model pembelajaran kooperatif tipe investigasi kelompok menggunakan model Plomp memenuhi kriteria kevalidan, kepraktisan, dan keefektifan untuk materi kesebangunan dan simetri menggunakan pembelajaran kooperatif tipe investigasi kelompok di kelas $\mathrm{V}$ sekolah dasar.

Namun dalam proses ujicoba lapangan terdapat beberapa kendala yang dihadapi peneliti. Kendala tersebut disajikan dalam tabel berikut.

Tabel 4. Kendala-kendala dalam Pembelajaran

\begin{tabular}{|c|c|}
\hline $\begin{array}{l}\text { Hal-hal yang perlu } \\
\text { dipertahankan }\end{array}$ & $\begin{array}{l}\text { Hal-hal yang perlu } \\
\text { diperbaiki }\end{array}$ \\
\hline 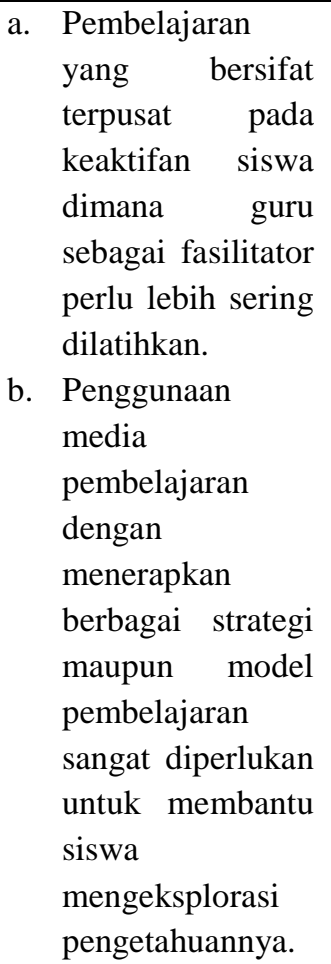 & $\begin{array}{l}\text { a. Perlunya } \\
\text { pembiasaan } \\
\text { pembelajaran } \\
\text { dengan } \\
\text { menggunakan } \\
\text { strategi maupun } \\
\text { model } \\
\text { pembelajaran yang } \\
\text { bersifat aktif dan } \\
\text { variatif agar siswa } \\
\text { lebih responsif } \\
\text { untuk membantu } \\
\text { mengembangkan } \\
\text { pengetahuan, sikap } \\
\text { dan keterampilan } \\
\text { siswa agar lebih } \\
\text { optimal. }\end{array}$ \\
\hline
\end{tabular}

Setelah ujicoba lapangan dan diperoleh perangkat pembelajaran yang layak, selanjutnya diterapkan dalam kelas dengan jumlah siswa yang lebih banyak. Adapun kelas implementasi ditetapkan pada siswa kelas VA SD Al Fatah. Pengajar dan pengamat pada kelas implementasi sama dengan kelas ujicoba lapangan. Sesuai dengan rancangan penelitian. Pelaksanaan pembelajaran dilaksanakan sesuai jadwal pelaksanaan sebanyak 6 kali pertemuan.
Subjek penelitian adalah siswa kelas VA SD Al Fatah Wiyung Surabaya yang berjumlah 25 siswa. Pada ujicoba peneliti bertindak sebagai guru dan dua orang guru kelas $\mathrm{V}$ bertindak sebagai pengamat terhadap kemampuan pengelolaan pembelajaran oleh guru dan aktivitas siswa. Data penerapan perangkat pembelajaran dengan model pembelajaran kooperatif tipe investigasi kelompok pada kelas implementasi meliputi:

1. Data kemampuan guru mengelola pembelajaran

Data kemampuan guru mengelola pembelajaran dikumpulkan melalui pengamatan menggunakan instrumen lembar pengamatan pengelolaan kegiatan pembelajaran pada setiap pertemuan. Pengamatan dilakukan oleh seorang pengamat (observer) sebanyak 3 kali sesuai pertemuan yang ditetapkan.

Aspek yang diamati terdiri yaitu: kegiatan pendahuluan, kegiatan inti, penutup, pengelolaan waktu dan suasana kelas. Analisis data pada hasil pengamatan diperoleh dari rerata setiap aspek kegiatan yang diamati. Berikut adalah hasil analisis terhadap kemampuan guru dalam mengelola pembelajaran yang secara ringkas ditampilkan dalam tabel berikut ini.

Tabel 5. Rekapitulasi Rata-rata Kemampuan Guru Mengelola Pembelajaran pada Kelas Implementasi

\begin{tabular}{llllll}
\hline No & $\begin{array}{l}\text { Aspek } \\
\text { Penilaian }\end{array}$ & P-1 & P-2 & P-3 & $\begin{array}{l}\text { Rata- } \\
\text { rata } \\
\text { tiap } \\
\text { Aspek }\end{array}$ \\
\hline 1 & $\begin{array}{l}\text { Pendahuluan } \\
\text { Kegiatan }\end{array}$ & 3,8 & 4,0 & 3,8 & 3,8 \\
$\quad \begin{array}{l}\text { inti } \\
3\end{array}$ & 3,3 & 3,3 & 3,2 & 3,3 \\
$4 \quad \begin{array}{l}\text { Penutup } \\
\text { Pengelolaan } \\
\quad \text { waktu dan }\end{array}$ & 4,0 & 4,0 & 4,0 & 4,0 \\
$\quad \begin{array}{l}\text { suasana } \\
\text { kelas }\end{array}$ & 3,0 & 3,3 & 3,3 & 3,3 \\
Rata-rata akhir \\
$\begin{array}{l}\text { Penilaian Tingkat } \\
\text { (TKG) }\end{array}$
\end{tabular}

Hasil pengamatan diperoleh rata-rata pada aspek pendahuluan adalah 3,8 aspek kegiatan inti adalah 3,3 aspek penutup adalah 4,0 dan aspek pengelolaan waktu dan suasana sebesar 3,3. Secara umum rata-rata penilaian RPP tiap pertemuan berkategori sangat baik dengan rerata akhir adalah 3,63. Pengamatan terhadap kemampuan guru mengelola pembelajaran pada kelas implementasi ini dapat disimpulkan bahwa kegiatan pembelajaran efektif, karena dilaksanakan sesuai rencana pembelajaran yang dikembangkan. 


\section{Hasil belajar siswa}

Data mengenai hasil belajar siswa dalam kelas implementasi meliputi: data tes hasil belajar yang mengukur ranah kognitif, data penilaian afektif yang mengukur ranah sikap, dan data penilaian psikomotor yang mengukur ranah keterampilan siswa. Uraian diskusi hasil belajar sesuai ranah masing-masing dijabarkan sebagai berikut:

a) Data tes hasil belajar (THB)

Data ini mengukur ketercapaian hasil belajar siswa pada ranah kognitif di kelas implementasi. Hasil diskusi tes hasil belajar siswa antara lain:

1) Hasil belajar siswa pada pre test menunjukkan bahwa 22 siswa dari 25 siswa berada di bawah nilai kriteria ketuntasan minimal. Hanya 3 siswa yang mencapai ketuntasan belajar secara individu. Rata-rata kelas menunjukkan nilai rerata 1,98/C (nilai 49,5). Ketuntasan belajar siswa secara klasikal sebesar $12,0 \%$. Artinya hasil pre test dinyatakan tidak tuntas.

2) Hasil belajar siswa pada post test menunjukkan bahwa sebanyak 19 siswa secara individu mencapai nilai kriteria ketuntasan minimal dan 6 siswa tidak tuntas secara individu. Rata-rata kelas diperoleh nilai rerata 2,98/B (nilai 74,5) Persentase siswa yang mencapai kriteria ketuntasan minimal secara klasikal setelah dilakukan post test sebesar 76,0\%. Artinya hasil post test siswa dinyatakan tuntas.

b) Data penilaian afektif

Data ini mengukur ketercapaian hasil belajar siswa pada ranah afektif di kelas implementasi. Hasil diskusi penilaian afektif siswa antara lain:

1) Modus ketuntasan belajar siswa secara individu menunjukkan bahwa 25 siswa seluruhnya memperoleh modus minimal baik.

2) Modus ketuntasan belajar siswa secara klasikal menunjukkan bahwa modus klasikal aspek 1 (tanggung jawab) adalah 3 berpredikat baik aspek 2 (rasa ingin tahu) adalah 4 berpredikat sangat aspek 3 (bekerjasama) adalah 3 berpredikat baik, dan aspek 4 (komunikasi) adalah 3 berpredikat baik. Modus klasikal kelas adalah 3 dengan predikat baik. Ketuntasan belajar siswa secara klasikal pada penilaian afektif ini menunjukkan persentase sebesar $100 \%$. Artinya penilaian afektif ini dinyatakan tuntas.

c) Data Penilaian Psikomotor.

Penilaian ini dilakukan melalui pengamatan oleh guru menggunakan instrumen penilaian. Teknik penilaian dilakukan melalui pengamatan terhadap unjuk kerja siswa membuat karya pigura foto. Indikator penilaian meliputi ketepatan mengukur, ketuntasan pembuatan, dan kerapian hasil membuat pigura foto yang menerapkan konsep kesebangunan. Hasil penilaian unjuk kerja siswa pada kelas implementasi ini sebagai berikut:

1) Capaian optimum ketuntasan belajar siswa secara individu menunjukkan bahwa 24 siswa dinyatakan tuntas dan 1 siswa tidak tuntas.

2) Capaian optimum ketuntasan belajar siswa secara klasikal menunjukkan bahwa pencapaian hasil belajar pada aspek ketepatan mengukur adalah 3,56 aspek ketuntasan pembuatan adalah 3,44 dan aspek kerapian hasil adalah 3,36. Capaian optimum kelas dari penilaian psikomotor sebesar 3,45/B+ berpredikat akhir baik. Persentase ketuntasan belajar secara klasikal mencapai 96,0\%. Artinya penilaian kinerja siswa dalam pembelajaran ini dinyatakan tuntas.

3. Aktivitas siswa dalam pembelajaran

Aktivitas siswa merupakan kegiatan siswa selama proses pembelajaran menggunakan perangkat pembelajaran yang telah dikembangkan sebagai acuan. Selama pembelajaran berlangsung, aktivitas siswa diamati oleh seorang pengamat selama 3 kali sesuai dengan jumlah pertemuan yang dilaksanakan dalam pembelajaran. Pengamatan dilakukan terhadap aktivitas yang dilakukan siswa setiap 5 menit sekali. Visualisasi aktivitas siswa dalam pembelajaran tersebut dapat disajikan melalui gambar diagram batang berikut.

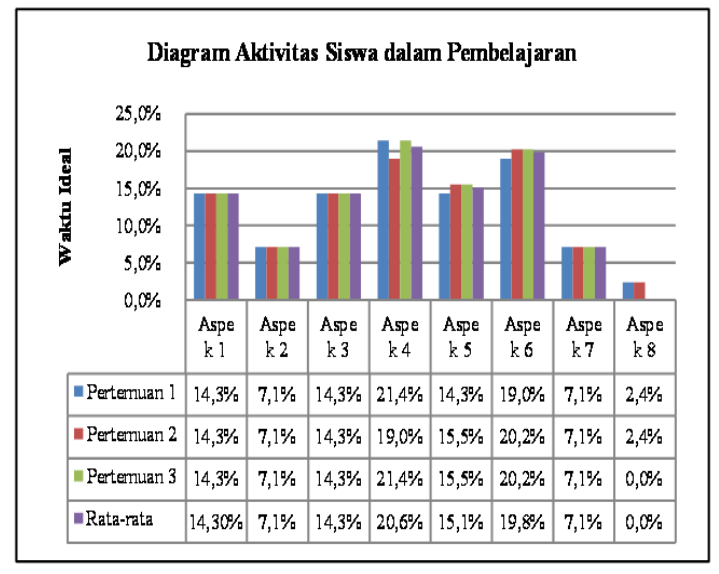

Gambar 6. Diagram Batang Hasil Pengamatan Aktivitas Siswa pada Kelas Implementasi

Berdasarkan diagram tersebut ditunjukkan bahwa rata-rata aktivitas siswa yang dominan yaitu berdiskusi dengan teman untuk melaksanakan kegiatan investigasi (Aspek 4) sebesar 20,6\% dan mempresentasikan laporan akhir kegiatan 
penyelidikan (Aspek 6) sebesar 19,8\%. Selama proses pembelajaran siswa secara aktif terlibat dalam kegiatan penyelidikan, berdiskusi, dan memaparkan hasil penyelidikan kepada kelompok lain. Hal ini sejalan dengan pembelajaran menurut Hobri (2010: 28) bahwa pembelajaran efektif dapat diciptakan dalam pembelajaran yaitu siswa secara aktif dilibatkan dalam kegiatan penemuan, siswa tidak hanya pasif menerima pengetahuan yang disampaikan guru tetapi mereka dapat memberikan tanggapan secara aktif.

Kesimpulan akhir hasil pengamatan pada kelas implementasi ini bahwa aktivitas siswa berada pada kriteria dengan toleransi waktu ideal. Secara keseluruhan aktivitas siswa selama pembelajaran dengan model pembelajaran kooperatif tipe investigasi kelompok pada materi kesebangunan dan simetri di kelas $\mathrm{V}$ sekolah dasar adalah efektif.

\section{Angket respon siswa}

Berkaitan dengan respon siswa terhadap pembelajaran, hasil analisis berdasarkan hasil angket diperoleh persentase rata-rata keseluruhan $\geq$ $80 \%$ yaitu sebesar $84,0 \%$ merespon positif dan $16,0 \%$ merespon negatif terhadap komponenkomponen pembelajaran kooperatif tipe investigasi kelompok.

Respon positif siswa bersesuaian dengan pendapat Thorndike (Karso,2012:123) yang menyatakan bahwa belajar merupakan proses pembentukan hubungan antara stimulus dan respon. Menurut teori belajar ini bahwa pembelajaran akan lebih berhasil bila respon siswa terhadap stimulus segera diikuti dengan rasa senang atau kepuasan. Pembelajaran yang efektif dipengaruhi oleh adanya minat perhatian siswa terhadap pembelajaran. Tingginya persentase siswa yang memberikan respon siswa mendukung tercapainya ketuntasan belajar siswa secara klasikal (Mudhofir 1990:146). Kesimpulan hasil respon siswa pada kelas implementasi yang menyatakan respon positif adalah $\geq 80 \%$ maka pembelajaran menggunakan pembelajaran kooperatif tipe investigasi kelompok ini efektif untuk diterapkan lebih luas.

Berdasarkan uraian hasil penerapan pengembangan perangkat pembelajaran pada kelas implementasi menggunakan model pembelajaran kooperatif tipe investigasi kelompok pada materi kesebangunan dan simetri di kelas $\mathrm{V}$ ini dapat disimpulkan bahwa perangkat pembelajaran ini memenuhi kriteria keefektifan jika diterapkan dalam lingkup lebih luas.
Beberapa kelemahan yang ada dalam penelitian ini antara lain (a) Uji keterbacaan LKS dan THB hanya dilakukan sekali sehingga tidak bisa menggambarkan kemampuan seluruh kelas. Sebaiknya uji keterbacaan dilakukan minimal 2 kali dengan siswa yang berbeda. (b) Pengamatan aktivitas siswa hanya satu kelompok saja, sehingga tidak dapat menggambarkan aktivitas siswa seluruh kelas. Sebaiknya pengamatan dilakukan banyak pengamat. (c) Pengembangan perangkat pembelajaran hanya terbatas pada materi kesebangunan dan simetri, sehingga tidak menutup kemungkinan perangkat pembelajaran serupa tidak tepat untuk materi yang lain.

Selain beberapa kelemahan terdapat pula temuan dalam penelitian ini berdasarkan hasil analisis data dan diperkuat hasil implementasi perangkat pembelajaran dapat diuraikan sebagai berikut: (a) Pemilihan dan penentuan strategi pembelajaran yang tepat oleh guru berdampak positif pada hasil belajar siswa. (b) Kegiatan belajar di kelas yang bervariatif menjadikan minat dan respon siswa untuk mengikuti pembelajaran lebih meningkat. (c) Kegiatan belajar yang bersifat kooperatif dan berpusat pada siswa menyumbangkan hasil belajar yang baik dan menyeluruh dari tiga aspek hasil belajar yaitu ranah hasil belajar kognitif, afektif dan psikomotor.

\section{PENUTUP}

Simpulan

Berdasarkan tujuan penelitian, hasil analisis data, dan diskusi hasil penelitian pengembangan menggunakan pembelajaran kooperatif tipe investigasi kelompok pada materi kesebangunan dan simetri di kelas $\mathrm{V}$ sekolah dasar diperoleh beberapa kesimpulan sebagai berikut:

1) Penelitian pengembangan ini menghasilkan perangkat pembelajaran menggunakan model pembelajaran kooperatif tipe investigasi kelompok pada materi kesebangunan dan simetri di kelas $\mathrm{V}$ sekolah dasar meliputi: rencana pelaksanaan pembelajaran (RPP), lembar kerja siswa (LKS), tes hasil belajar siswa (THB), instrumen penilaian yaitu lembar penilaian afektif dan lembar penilaian psikomotor.

2) Perangkat pembelajaran yang dikembangkan memenuhi kriteria perangkat yang layak/berkualitas setelah melalui tahap validasi, ujicoba lapangan dan implementasi. 
Ketercapaian kriteria perangkat yang baik tersebut adalah:

a) Kriteria kevalidan perangkat pembelajaran:

1) Rencana Pelaksanaan Pembelajaran (RPP) dengan rata-rata total validitas 3,7 berkriteria valid.

2) Lembar Kerja Siswa (LKS) dengan ratarata total validitas 3,7 berkriteria valid.

3) Tes Hasil Belajar (THB) dengan rata-rata total validitas 3,4 berkriteria valid.

4) Lembar Penilaian Afektif dengan ratarata total validitas 3,4 dan berkriteria valid.

5) Lembar Penilaian Psikomotor dengan rata-rata total validitas 3,5 dan berkriteria valid.

6) Validitas butir tes dengan koefisien validitas tiap butir tes $\geq 0,4$ dan berkategori cukup.

7) Reliabilitas butir tes dengan koefisien reliabilitas $\alpha=0,73$ dan berderajat sedang.

b) Kriteria kepraktisan perangkat pembelajaran:

Kemampuan guru mengelola pembelajaran dengan rata-rata akhir 3,6 dan penilaian umum sangat baik.

c) Kriteria keefektifan perangkat pembelajaran:

1) Data tes hasil belajar (THB) dengan ketuntasan belajar siswa secara individu sebanyak 15 siswa dari 19 siswa. Ketuntasan belajar siswa secara klasikal mencapai $78,9 \%$ rata-rata kelas 3,28/B+ dan berkategori tuntas.

2) Data hasil penilaian afektif dengan ketuntasan belajar siswa secara individu sebanyak 17 siswa dari 19 siswa. Ketuntasan belajar siswa secara klasikal mencapai $89,5 \%$. Modus klasikal adalah 3 berpredikat akhir baik dan berkategori tuntas.

3) Data hasil penilaian psikomotor dengan ketuntasan belajar siswa secara individu sebanyak 18 siswa dari 19 siswa. Ketuntasan belajar siswa secara klasikal mencapai $94,7 \%$. Capaian optimum kelas 3,61/A- dan berkategori tuntas.

4) Data aktivitas siswa dalam pembelajaran dengan penilaian umum efektif sesuai batas kriteria toleransi $10 \%$.
5) Data angket respon siswa dengan respon positif siswa $83,5 \%$ dan respon negatif siswa $16,5 \%$.

3) Pembelajaran matematika menggunakan model pembelajaran kooperatif tipe investigasi kelompok pada materi kesebangunan dan simetri di kelas V sekolah dasar ini efektif. Hal ini ditunjukkan dengan:

a) Kemampuan guru dalam mengelola pembelajaran dengan skor rata-rata akhir 3,63 dan penilaian umum sangat baik.

b) Ketuntasan hasil belajar siswa meliputi:

1) Data tes hasil belajar (THB) dengan ketuntasan belajar siswa secara individu sebanyak 19 siswa dari 25 siswa. Ketuntasan belajar siswa secara klasikal mencapai $76,0 \%$ dengan rata-rata kelas 2,95/B dan berkategori tuntas.

2) Data hasil penilaian afektif dengan ketuntasan belajar siswa secara individu sebanyak 25 siswa. Ketuntasan belajar siswa secara klasikal mencapai $100 \%$. Modus klasikal 3 berpredikat akhir baik dan berkategori tuntas.

3) Data hasil penilaian psikomotor dengan ketuntasan belajar siswa secara individu sebanyak 24 siswa dari 25 siswa. Ketuntasan belajar siswa secara klasikal mencapai 96,0\% dengan capaian optimum kelas 3,45/B+ dan berkategori tuntas.

c) Aktivitas siswa dalam pembelajaran dengan penilaian umum sesuai batas kriteria dengan toleransi $10 \%$.

d) Respon siswa terhadap perangkat pembelajaran sebagian besar merespon positif dengan persentase mencapai $84,0 \%$ dan respon negatif siswa $16,0 \%$.

Saran

Berdasarkan hasil penelitian dan pengalaman peneliti selama melakukan penelitian, peneliti memberikan saran sebagai berikut:

1) Pengembangan perangkat pembelajaran matematika menggunakan model pembelajaran kooperatif tipe investigasi kelompok dapat digunakan sebagai alternatif pembelajaran pada materi kesebangunan dan simetri di kelas $\mathrm{V}$ sekolah dasar.

2) Hasil respon siswa positif terhadap hasil pengembangan perangkat pembelajaran, maka perlu dikembangkan model pembelajaran 
kooperatif tipe investigasi kelompok pada materi lain.

3) Hendaknya peneliti lain menindaklanjuti hasil penelitian ini untuk menyempurnakan atau setidaknya mengurangi kelemahan-kelemahan dalam penelitian, agar diperoleh hasil penelitian yang lebih akurat.

\section{DAFTAR PUSTAKA}

Airasian, W. Peter, Cruikshank, A. Kathleen, Mayer, E. Richard, Pintrich, R. Paul, Raths, James R., Wittrock, C. Merlin. (2001). "Revisi Taksonomi Pendidikan Bloom", (Terjemahan) dalam Anderson, W. Lorin dan Krathwohl, R. David (Editor). Kerangka Landasan untuk Pembelajaran, Pengajaran, dan Asesmen. Yogyakarta: Pustaka Fajar.

Arifin, Z. (2010). Membangun Kompetensi Pedagogis Guru Matematika. Surabaya: Lentera Cendikia.

Arikunto, S.(2012). Dasar-Dasar Evaluasi Pendidikan. Jakarta: Bumi Aksara.

Astuti,Y.(2012). "Pengembangan Perangkat Pembelajaran Matematika Realistik dalam Upaya Meningkatkan Prestasi Belajar Matematika Siswa Sekolah Dasar di Kecamatan Rendang”. Jurnal Matematika dan Sains Undiksha Singaraja (Online).(Tersedia:

http://digilib.undiksha.edu, diakses 2 Maret 2015).

Daryanto.(2013). Inovasi Pembelajaran Efektif. Bandung: Yrama Widya.

Depdiknas. (2008). Panduan Pengembangan Bahan Ajar. Jakarta: Dirjen Dikdasmen.

Depdiknas. (2006). Kurikulum Tingkat Satuan Pendidikan (KTSP). Jakarta: Dirjen Dikdasmen.

Etherington, B. Matthew. (2011). "Investigative Primary Science: A Problem Based Learning Approach". Australian Journal of Teacher Education. Vol 36 No. 9. pp. 52-53.

Firman,Harry. (1987). Keefektifan Program Pembelajaran

(http://ahmadmuhli.wordpress.com/2011/08/

02/efektivitas-pembelajaran/,diakses $\quad 28$

Agustus 2015)

Hariyanti.(2010).“Pengembangan Perangkat Pembelajaran Melalui Pendekatan Investigasi untuk Meningkatkan Kemampuan Penalaran Matematika Siswa Kelas VII C SMP Negeri 2 Depok Sleman”.
Jurnal Matematika dan Ilmu Pengetahuan (Online), Jilid 5, No.4 (http:/ /pps.uny.ac.id/ perpustakaan, diakses 17 Januari 2015).

Hayuhantika,D.(2010)."Pengembangan Perangkat Pembelajaran Matematika Berciri Investigasi pada Pokok Bahasan Kesebnagunan dan Kekongruenan untuk Kelas X" Jurnal Matematika dan Sains (Online),Jilid VII, No. 102. (http:// pps. unm.ac.id/ perpustakaan, diakses 23 Juni 2015).

Hermawan. (2012). "Implementasi Pendekatan Investigasi dengan Strategi Pembelajaran Kooperatif Tipe STAD Terhadap Kemampuan Pemecahan Masalah Matematika Siswa Sekolah Dasar". Unnes Journal of Research Mathematics Education (Online), (http://journal.unnes.ac.id/sju/ index. php/ujrme, diakses 15 Desember 2014).

Hobri. (2010). Metodologi Penelitian Pengembangan. Aplikasi pada Penelitian Pendidikan Matematika. Jember: Pena Salsabila.

Hudoyo, H. ( 2005). Strategi Belajar Matematika. Malang : IKIP Malang.

Ibrahim, M. (2003). Pembelajaran Kooperatif Surabaya: Unesa University Press.

Joyce, B. Weil, M.\& Shower, B. (2011). Models of Teaching (4th edition). Englewood Cliff, N.J. : Prentice-Hall.

Kamus Besar Bahasa Indonesia. (Online). Tersedia: http://kbbi.web.id/, diakses 5 Januari 2015.

Karim, Djamari. (2009). Penilaian Pendidikan Karakter. (Online) Tersedia: (www.academia.edu/4705714/

Penilaian_karakter, diakses 27 September 2015).

Karso, dkk. (2012). Pendidikan Matematika 1. Tangerang: Universitas Terbuka.

Khabibah, S. (2006). Pengembangan Model Pembelajaran Matematika dengan Soal Terbuka untuk Meningkatkan Kreativitas Siswa Sekolah Dasar. (Disertasi PPs Unesa Surabaya tidak dipublikasikan): Universitas Negeri Surabaya.

Lampiran Peraturan Bersama Direktorat Jenderal Pendidikan Dasar dan Menengah Nomor 5496C dan 7915D Tahun 2014 Tentang Petunjuk Teknis Pemberlakuan Kurikulum 2006 dan Kurikulum 2013 pada Sekolah 
Jenjang Pendidikan Dasar dan Menengah. Jakarta: Kemendikbud.

Lampiran Permendikbud Nomor 104 Tahun 2014 tentang Pedoman Penilaian Hasil Belajar oleh Pendidik. Jakarta: Kemendikbud.

Mudhofir. (1990). Teknologi Instruksional. Bandung: Remaja Rosdakarya.

Mulyasa, H.E. (2014). Pengembangan dan Implementasi Kurikulum 2013. Bandung: Remaja Rosda Karya.

Musta'in.(2014).Pengembangan Perangkat Pembelajaran Kooperatif Tipe STAD Berbantuan Software Geogebra untuk Materi Dimensi Tiga Kelas X SMA Al Azhar (Tesis PPs Unesa Surabaya tidak dipublikasikan). Universitas Negeri Surabaya.

Nieveen, N. (1999). Prototyping to Reach Product Quality. dalam Plomp, T; Nieveen, N; Gustafson, K; Branch, R.M; dan van den Akker, J (eds). Design Approaches and Tools in Education and Training. London: Kluwer Academic Publisher.

Nur, M. \& Wikandari, R. Prima. (2008). Pengajaran Berpusat kepada Siswa dan Pendekatan Konstruktivis dalam Pengajaran. Surabaya: Pusat Sains dan Matematika Sekolah, Unesa.

Purwanto, N. (2009). Prinsip-Prinsip dan Teknik Evaluasi Pengajaran. Edisi Revisi. Bandung: Remaja Rosda Karya.

Ratumanan,T.G. \& Theresia, L. (2003). Penilaian Hasil Belajar pada Tingkat Satuan Pendidikan Edisi 2. Surabaya: Unesa University Press.

Riduwan. (2004). Metode dan Teknik Menyusun Tesis. Bandung: Alfabeta.

Santrock, W. John. (2011). Psikologi Pendidikan. Jakarta: Kencana Prenada Media Group.

Setiani.(2010)."Penggunaan Metode Investigasi Kelompok dalam Pembelajaran Matematika untuk Meningkatkan Berfikir Kritis Matematis pada Siswa Kelas VI SD Negeri Plosokandang". Journal of Primary Education. (Online). JPE Volume 1, No(4), (http://journal.unnes.ac.id /sju/ index. php/jpe), diakses 20 September 2015.

Shadiq, F. (2007). Investigasi atau Penyelidikan dalam Proses Pembelajaran Matematika. Yogyakarta : PPPG Matematika.
Slavin, Robert E. (2011). Psikologi Pendidikan: Teori, dan Praktik. (Terjemahan) Jakarta: PT Indeks.

Slavin, Robert E. (2011). Cooperative Learning: Teori, Riset dan Praktik. (Terjemahan) Bandung: Nusa Media.

Soedjadi. (2000). Kiat Pendidikan Matematika di Indonesia. Jakarta: Direktorat Jendral Pendidikan Tinggi Departemen Pendidikan Nasional.

Sudijono, A. (2008). Pengantar Statistika Pendidikan. Jakarta: Raja Grafindo Persada..

Sudjana, N. (2005). Metode Statistika. Bandung: Tarsito.

Sugiyono. (2008). Metode Penelitian Pendidikan (Pendekatan Kuantitatif, Kualitatif, dan $R \& D)$. Bandung: Alfabeta.

Suminarsih. (2007). Model-model Pembelajaran Matematika. Semarang: Widyaiswara.

Suwangsih, E. dan Tiurlina. (2006). Model Pembelajaran Matematika. Bandung: UPI PRESS. Bandung.

Trianto. (2011). Mendesain Model Pembelajaran Inovatif-Progresif: Konsep, Landasan, dan Implementasinya pada Kurikulum Tingkat Satuan Pendidikan (KTSP). Jakarta: Kencana Prenada Media Group.

Usman, M. Uzer,. (2001). Menjadi Guru Profesional. Bandung: Remaja Rosdakarya.

Utari, R. (2011). Taksonomi Bloom Apa dan Bagaimana Menggunakannya? Semarang: Widyaiswara.

Van De Walle, J. (2007). Elementary and Middle School Mathematics Sixth Edition. Pearson Education, Inc.

Warli. (2007). "Pembelajaran Matematika Realistik Materi Geometri Kelas IV MI". (Online). Jurnal Pendidikan Matematika. http:// ejournal. unirow. ac.id/ojs/files/journals/2/articles/4/public/ jurnalwarli-4.pdf.(diakses pada 11 Juni 2015).

Warsono dan Hariyanto. (2012). Pembelajaran Aktif Teori dan Asesmen. Bandung: Remaja Rosdakarya.

Widoyoko, P. Eko, S. (2007). Teknik Penyusunan Instrumen Penelitian. Yogyakarta: Pustaka Pelajar.

Zulhelmi. (2007). Penilaian Hasil Belajar Mata Pelajaran Fisika. Pekanbaru: Cendikia Insani. 